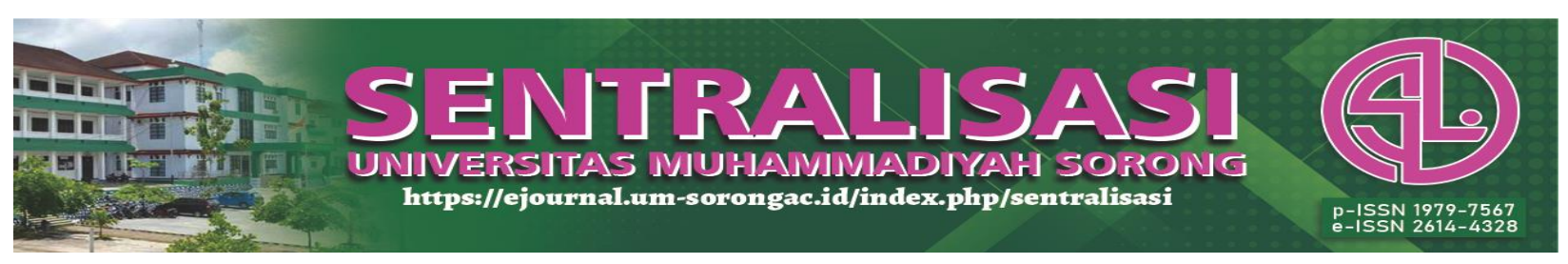

\title{
Accountability For Immediate Assistance In Village Fund (Case Study in Lesmana Village, Banyumas Regency)
}

\author{
Herliana $^{1}$, Oman Rusmana ${ }^{2}$ \\ ${ }^{1,2}$ Faculty of Economics and Business, University of General Soedirman, Indonesia.
}

\section{E-mail : $\underline{\text { mr.herliana@gmail.com }}$}

direvisi: 25/01/2021 dipublikasikan: 31/01/2021

\begin{abstract}
Abstrak. Pademi Covid-19 berdampak terhadap penurunan pendapatan masyarakat, bantuan langsung tunai yang bersumber dari dana desa menjadi salah satu solusi agar masyarakat miskin dapat bertahan dimasa pademi. Tujuan penelitian untuk melihat bagaimana desa Lesmana melakukan relokasi dana desa menjadi bantuan langsung tunai, serta melihat akuntabilitas pengelolaan BLT Dana Desa. Jenis penelitian kualitatif dengan study kasus, data yang dipakai adalah data primer dari hasil observasi, wawancara, angket dan data sekunder dari study pustaka. Hasil penelitian memperlihatkan bahwa relokasi dana desa menjadi bantuan langsung tunai di desa Lesmana telah sesuai dengan peraturan yang ada, begitu pula dalam hal pengelolaan sudah dilakukan dengan cukup akuntabel.
\end{abstract}

Kata kunci: Pademi Covid-19, Dana Desa, BLT Dana Desa, Akuntabilitas

\begin{abstract}
Pandemic Covid-19 has an impact on decreasing community income, direct cash assistance sourced from village funds is one solution so that the poor can survive their prime. The research objective was to see how the village of Lesmana relocated village funds into direct cash assistance, as well as to see the accountability of the Village Fund BLT management. This type of qualitative research with case studies, the data used are primary data from observations, interviews, questionnaires and secondary data from literature studies. The results showed that the relocation of village funds to direct cash assistance in the village of Lesmana was in accordance with existing regulations, as well as in terms of management it was carried out quite accountably.
\end{abstract}

Keywords: Pandemic Covid-19, Village Fund; Village Fund BLT; Accountability

\section{Introduction}

The Covid -19 Pademi that occurred in 2020 has been a devastating blow to the world economy. Indonesia is one of the countries that have been economically affected by the Covid-19 pandemic. Rural communities are the ones most economically affected by the Covid-19 pandemic . Many rural communities have lost their livelihoods, some have lost their jobs because the company they worked for was forced to close due to the Covid-19 pandemic. This condition forces the village government to find a solution so that the affected communities can survive during the pademi period, namely by providing financial assistance taken from village funds. Village funds are village incomecomes from the APBN which is distributed annually by the central government to the village government. Village funds are intended to fund the needs of the village government, finance infrastructure and superstructure in the village, empowerment programs for village communities and disaster management. The occurrence of the Covid -19 pandemic has forced the government to change the allocation of village funds to deal with the 


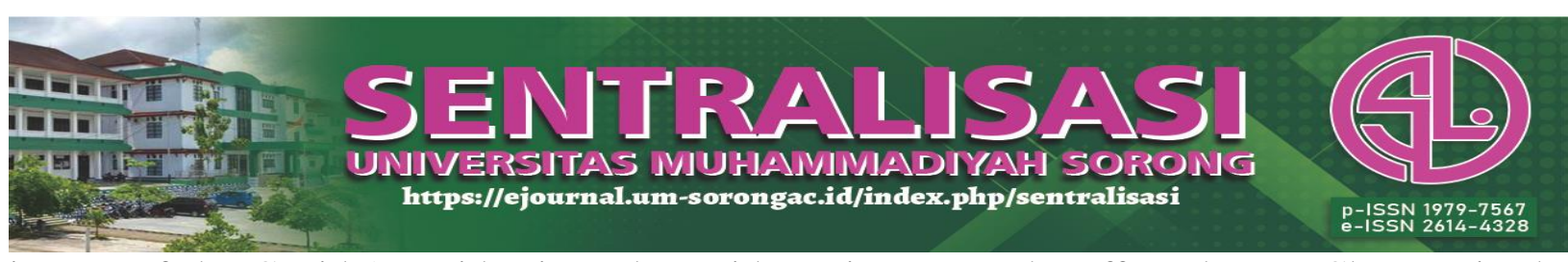

impact of the Covid-19 epidemic and provide assistance to the affected poor. Changes in the allocation of village funds from physical development, operations and empowerment to Direct Cash Assistance (BLT) have the potential to cause problems both in the process of allocating village funds, implementing realization and reporting on the implementation of assistance, so that supervision of all processes that occur is required .

The Village Fund BLT is financial assistance for the poor during the Covid -19 period, this is stated in the Village Ministerial Regulation (Menteri Desa, Pembangunan Daerah Tertinggal, 2020). The regulations regarding the Village Fund BLT are explained as follows: (1). The Village Fund BLT is aimed at poor people who have felt the impact of the Covid-19 pandemic but have not received social assistance from the government. Beneficiaries are prioritized for those who have lost their jobs or whose family members are seriously ill. (2). Data collection of potential aid recipients was carried out in stages by village volunteers against Covid-19 by collecting data in stages starting from the RT, RW to the village level. After the data collection is complete, it is continued with a village meeting to determine the list of BLT Village Fund recipients. Documents that have been validated by village meetings are then signed by the village head Then the village head submits a report to the local sub-district head to be forwarded to the Regent / Mayor. The activity of providing assistance must be carried out after five reports have arrived at the sub-district . (3). The location of assistance from village funds is determined according to the amount of village fund received. You can propose for additional additional allocations to the district / city government if the number of poor families is greater than the budget allocation. The realization mechanism is attempted by using the non-cash method and is carried out every month. (4 ). The implementation time of the Village Fund BLT is carried out for a period of six months, namely from April 2020 to September 2020. Realization of the first phase, namely the first month to the third month, the amount of assistance is Rp. 600,000, while the amount for the second phase, namely the fourth month to the sixth month IDR 300,000 . (5 ). Village Fund BLT activities are monitored and evaluated by the Village Consultative Body (BPD), the subdistrict and the Regency / City Inspectorate . (6 ). Village Fund BLT activities must be held accountable by the village head. (7). The relocation of village funds to BLT Village Funds must be contained in the Amendment APBDes by still referring to applicable regulations.

Pademi conditions that force people to stay indoors make it difficult for most people to find sources of income to meet their daily needs. Their BLT Dana Village is expected to help especially for people poor are affected pademi in order to survive and be able to meet the needs of basic them. Many researches on the implementation of village funds for handling Covid-19 have been carried out, such as (Amalia et al., 2020; Ayu et al., 2020; Saleh et al., 2020) shows that there has been a relocation of village funds to handle Covid-19. While (Maun, 2020; Pramanik, 2020) found that direct cash assistance had an effect on the survival of the community during the Covid-19 pandemic. Research by (Hidayat, 2020; Rahmansyah et al., 2020) found that

Herliana 


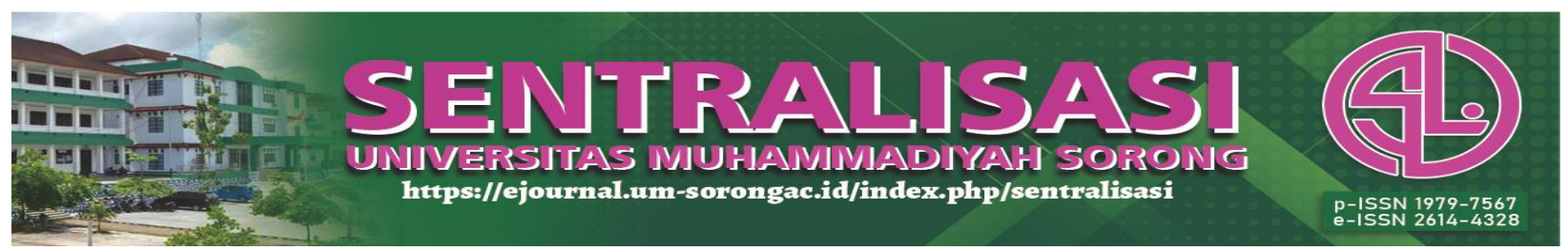

the implementation of village fund policies for handling Covid 19 can be successful if there is good cooperation from all parties and is complemented by a good system .

The relocation of village funds into direct cash assistance has proven to play an important role in the survival of the community during the pademic period. However, we also understand that the relocation of village funds to direct cash assistance is very likely in its implementation to be ineffective and not on target. To ensure that the Village Fund BLT has been managed properly, namely through management accountability. Accountability is a form of responsibility for the success or failure of the management of a $\mathrm{n}$. Accountability is an evaluation tool and a control tool over the process of managing an activity carried out. The accountability of village fund management has an important role to play in ensuring that village funds have been managed in accordance with applicable regulations and are aimed at improving the welfare of village communities.

Some studies history shows things are (Hanifah \& Sugeng, 2015) shows that the village government has been doing management of funds village is accountable. Different research results were conveyed by (Nurfaisal et al., 2019) found that the accountability of village fund management is still not good. Research which conducted (Saputra et al., 2019) found the effect of accountability on efforts to prevent fraud in the management of village funds. Besides that, the accountability is also an effect on the increase of Good Government Governance as found in the study (Asmoro \& Setianingsih, 2019). Research else do (Susliyanti \& Binawati, 2020) find that the accountability of an effect on the satisfaction and confidence of society on the use of funds the village .

Management of cash transfers of funds expected to be made accountable village BLT Village Fund that can be channeled in the right target. Research on BLT Village Funds has focused more on the impact of BLT Village Funds on the community economy during the Covid-19 pandemic , but research on the disbursement process of Village Fund BLT is still very rare. One aspect of the Village Fund BLT that has not yet been studied is the accountability aspect of the Village Fund BLT management. The results of the researchers' search found that until this research was carried out, there had been no other studies regarding the accountability of the Village Fund BLT.

\section{Research Methods}

The type of research used is qualitative research with a case study model. The research was conducted in Lesmana Village, Ajibarang District, Banyumas Regency, Central Java Province, Indonesia. The population of this study were 197 villagers who received BLT Dana Desa in Lesmana Village. The data used in this research are two types of data, namely primary data in the form of interviews and questionnaire results and secondary data in the form of reports on the realization of Village Fund BLT distribution. The informants in this study consisted of 1 representative of the Village Consultative Body (BPD), 3 village officials, namely the village head, 


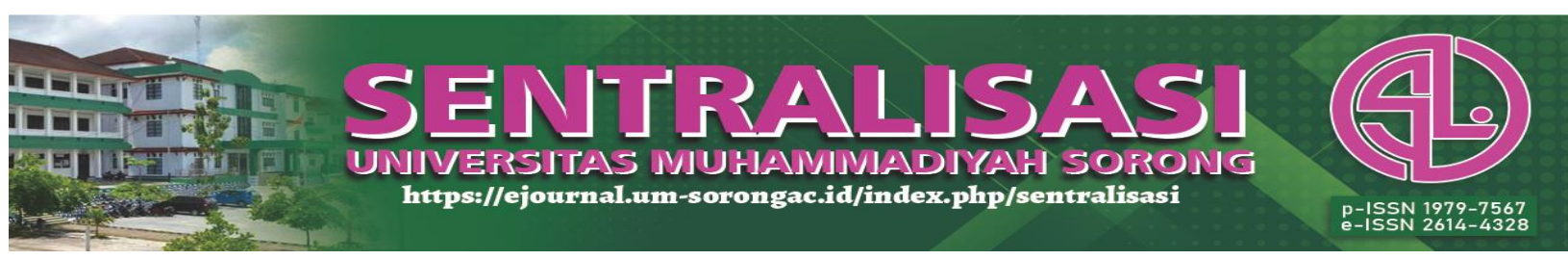

the finance department and implementers of the Village Fund BLT program in Lesmana village and 41 representatives of the Village Fund BLT program. The selection of informants from the community was carried out by using purposive sampling technique. Data collection techniques through questionnaires, interviews, and literature study.

Good data will greatly determine the results of research, in connection with this, researchers use several methods in data collection, namely through the researchers themselves who directly study the field, complete with field notes, conduct interviews in accordance with the interview guide made. by researchers, as well as distributing semi-open questionnaires to respondents who came from the Village Fund BLT recipient community. Researchers did source triangulation, which was done by checking data from different sources and technical triangulation, which was collecting data with different techniques. The collected data were analyzed in stages, namely data collection, data presentation, data verification and drawing conclusions (Miles \& Huberman, 1994).

\section{Result and Discussion}

\section{Impact of Pademi Covid-19 for Residents of Lesmana Village}

Lesmana Village is located in Ajibarang sub-district, Banyumas Regency, Central Java Province. Lesmana village covers 208.13 hectares consisting of 3 hamlets, 12 RW and 41 RT. The total population of Lesmana Village is quite large, namely 6,737 people with 2,157 households. The large number of residents makes Lesmana village a village with a fairly dense population density. Most of the livelihoods of the people of Lesmana are farming and gardening, while others work as small traders (UMKM) and casual daily laborers, this makes Lesmana one of the villages with a high poverty pocket. Currently in Lesmana Village, there are 1,057 households in the poor category, 971 in the middle category and only 129 in the rich category.

Pademi Covid-19 resulted in a decrease in the income and income of the villagers of Lesmana. Sales of agricultural produce have fallen dramatically as markets have closed and public spending has declined. The impact of the decline in income was also felt by residents who work as small traders (MSMEs), even some traders who used to sell in the school environment were forced to close because online school policies made schools deserted. The impact is very big for casual daily laborers, many of whom do not work because of the reduction in development projects, both government and private. In general, almost all residents of Lesmana village were economically affected because of the Covid-19 pandemic, what makes the difference is economic resilience. Communities with permanent incomes such as Civil Servants (PNS) and Private Employees tend to be more resilient economically, while people with irregular incomes such as farmers, small traders and daily laborers experience a much heavier impact, because generally they experience a decline. lost source of income.

Herliana 


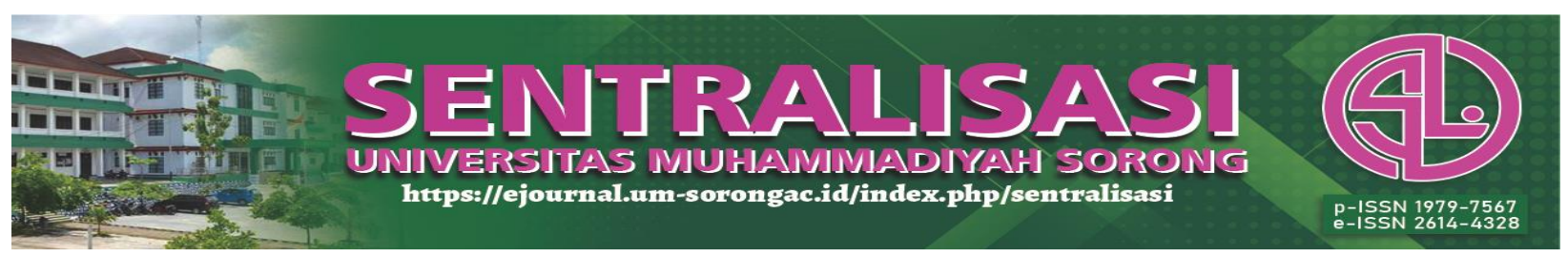

\section{Relocation of Village Funds to become Village Fund BLT}

The impact of the Covid -19 pandemic on the economy of the community, especially the poor, was extraordinary. Many people whose income has decreased even have no income at all. This condition is taken seriously by the government in the form of providing social assistance in the form of cash assistance and basic food assistance. One form of cash assistance is direct cash assistance originating from village funds.. The relocation of village funds into direct cash assistance is one of the programs carried out by the Lesmana village government. The direct cash assistance is expected to provide a temporary solution for the villagers of Lesmana during the C ovid-19 period. This assistance is very useful to meet the basic needs of the poor in Lesmana village, especially for people who have lost their jobs or cannot sell anymore due to the impact of the Covid-19 pandemic.

To examine how the process of relocating village funds to direct cash assistance, researchers conducted field observations by being directly involved in the Village Deliberative Meeting activities to determine the list of Village Fund BLT recipients. Observations were made by researchers during the village deliberation process, starting from the process of submitting data from the village government, deliberations by community representatives (RT heads and RW heads) to the determination process by the Village Consultative Body (BPD). The next stage, the researcher conducted interviews with village government representatives, namely the village head, village secretary and village finance division regarding the stages of relocating village funds to Village Fund BLT. Interviews were also conducted with representatives of the Village Consultative Body (BPD), namely the Chairman of the Lesmana Village BPD. Interviews were conducted in a structured manner, questions were first compiled by the researcher and then asked to all respondents. To complete the information, the researcher also conducted a study of village regulations regarding the relocation of village funds to direct cash assistance. To relocate village funds into direct cash assistance, the village government of Lesmana issued 2 regulations, namely the Regulation of the Village Head of Lesmana No.3 of 2020 concerning the 2nd Amendment of the Elaboration of APBDes for Fiscal Year 2020 and Regulation of the Village Head of Lesmana No.4 of 2020 concerning the Determination of Recipient Families Benefits of Village Fund BLT. These two regulations serve as guidelines for the implementation of village fund relocation into direct cash assistance for the people of Lesmana village.

During the year 2020, the village government Lesmana has made relocation village funds into BLT Village Fund that were administered in three stages of acceptance. The Village Fund BLT phase 1 for the first receipt, the second receipt and the third receipt is IDR 118,200,000, the Village Fund BLT stage 2 for the fourth receipt, the fifth receipt and the sixth receipt have changed according to the regulations to become IDR 59,100,000 and BLT Dana The village stage 3 for the seventh acceptance, the eighth acceptance and the ninth acceptance underwent another change due to adjusting the remaining village funds to Rp 22,200,000. During 2020 the village 


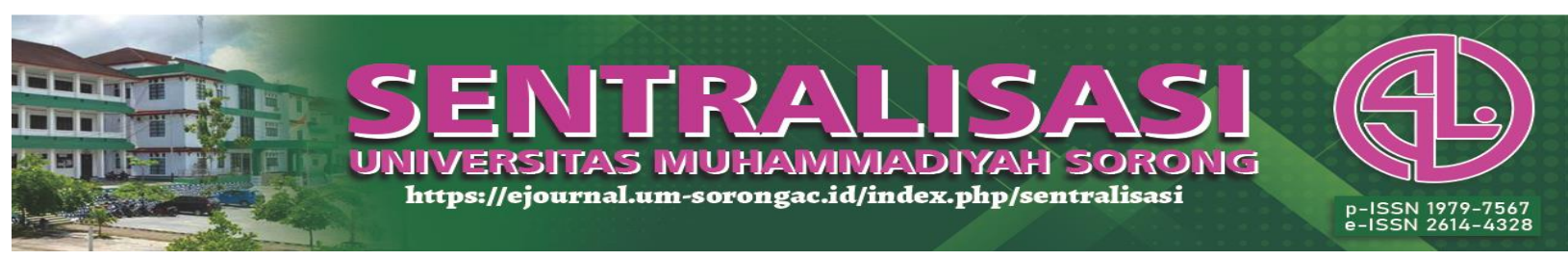

government of Lesmana has relocated village funds to direct cash assistance of IDR $199,500,000$. The relocation of village funds into direct cash assistance by the Lesmana village government during 2020 is in accordance with village regulations and regulations issued by the central government.

\section{Implementation of Village Fund BLT Realization}

The implementation of the BLT Village Fund in Lesmana village is carried out in accordance with the stages that have been determined by the government. The initial stage was preceded by data collection of potential beneficiaries by the village government based on suggestions from the RT and RW heads. Data on prospective recipients of proposals from RT heads and RW heads are then verified by the village government to ensure that the prospective recipients have not received other social assistance. The next stage, the village government held a village meeting to determine potential recipients of the Village Fund BLT. The village deliberation was attended by elements of the village administration, the Village Consultative Body (BPD), the head of the RW, the head of the RT and invitations from representatives of the Ajibarang District, village assistants, babinsa and village police. Data on potential recipients that have been verified are then discussed in deliberations and determined as potential recipients of the Village Fund BLT. During 2020, the village of Lesmana held 3 village meetings, namely on May 17, 2020, July 6, 2020 and October 27, 2020. The first village meeting on May 17, 2020 determined that the Village Fund BLT recipient candidates were 197 poor families with an amount received of Rp. 600,000 received three times, namely the first, second and third receipts. The second village meeting on July 6, 2020 determined that the candidates for Village Fund BLT were still the same, namely 197 poor families but the amount received changed to Rp. 300,000 which was received three times, namely the fourth, fifth and sixth receipts . The third village meeting held on October 27, 2020 set BLT Village Fund recipients are as many as 80 poor families with the amount received Rp 300,000 which were administered three times, namely acceptance of unity, second and third were administered three times, namely acceptance of the seventh, eighth and ninth. After village deliberations determine the list of Village Fund BLT recipients, the next stage is the disbursement of the Village Fund BLT.

Disbursements were made directly by the village government to aid recipients. The beneficiary community received an invitation to take assistance at the village hall of Sono Laras, Lesmana Village. Disbursement times were carried out with different schedules for each beneficiary in order to avoid crowds and queues of beneficiaries. Beneficiaries are required to apply health protocols, they must wear a mask, wash their hands before taking assistance and keep their distance while waiting for the scheduled assistance. People who have received aid sign the receipt of aid that has been prepared by the village government. After the assistance has been distributed to the community who received the Village Fund BLT, the village government makes a report on the realization of the Village Fund BLT. The aid realization report contains minutes 


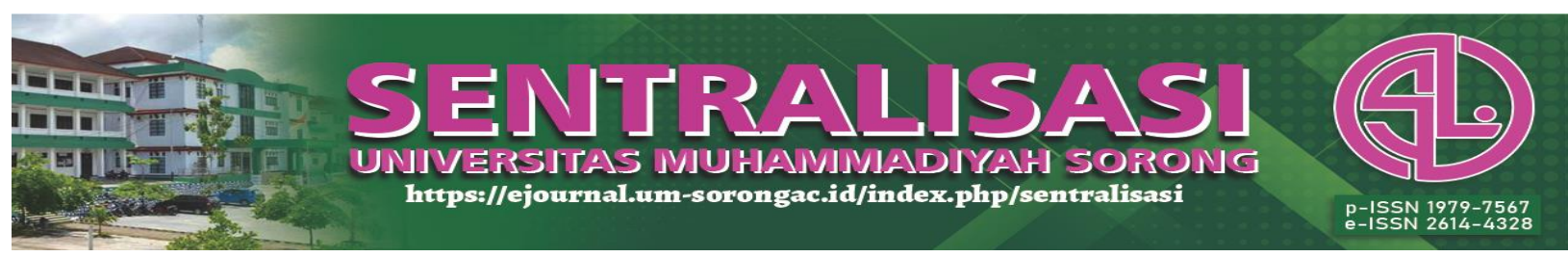

of village deliberations, data on aid recipients, the amount of aid distributed and documentation of activities. The report was then submitted to the Banyumas Regency government. The Village Fund BLT realization report was also submitted to the Lesmana Village BPD as the representative of the Lesmana village community. However, in the third phase of the Village Fund BLT realization report for the seventh, eighth and ninth BLT Village Fund, there were 6 recipients of Village Fund BLT whose funds were not realized and were withdrawn because after re-verification they had received other social assistance. The BLT Village Fund funds are then put back into the Lesmana village fund treasury.

\section{Village Fund BLT Accountability}

Seeing the importance of BLT Village Funds for the people of Lesmana village, the Lesmana village government ensures that the assistance process has been carried out according to regulations and is right on target and is managed accountably. The accountability of the Village Fund BLT was carried out starting from the socialization of the assistance program to the Lesmana village community, involving community elements in determining the list of beneficiaries, and publication of the realization report. To find out more about the accountability of BLT Dana Desa in Lesmana village, researchers conducted field visits, conducted interviews and distributed semiopen questionnaires to Village Fund BLT recipients. Respondents were selected by purposive sampling technique and obtained as many as 41 people representing 41 RT in Lesmana village. Based on the results of the survey found that they are poor candidates for beneficiaries not so accept because they get social assistance other. This is evidenced by the results of the questionnaire, where out of 41 respondents who became informants 40 people received BLT Village Fund 1 person did not receive it because they had received non-cash food assistance. This condition shows that the data for potential Village Fund BLT recipients that have been verified by the village is not $100 \%$ accurate because they have not been synchronized with all other social assistance such as PKH Regular, PKH Covid, and BPNT which are distributed to residents of Lesmana village. Assistance funds that were not disbursed and were canceled to be disbursed were returned to the Lesmana village treasury. The existence of assistance that is not distributed shows that data on the poor receiving aid in the village of Lesmana needs to be updated and synchronized with existing data in other agencies such as data in the Ministry of Social Affairs .

From the survey results also obtained data that the amount received by the people who were entitled to Village Fund BLT was not all the same as the amount that had been determined. For example, the phase 1 disbursement of the allocation for each BLT Village Fund recipient was IDR 600,000, but of the 41 informants only 9 received IDR 600,000, 31 people received less than IDR 600,000 and 1 person did not receive it because they had received BNPT. Although 31 people received an amount of less than Rp. 600,000, this is not the fault of 


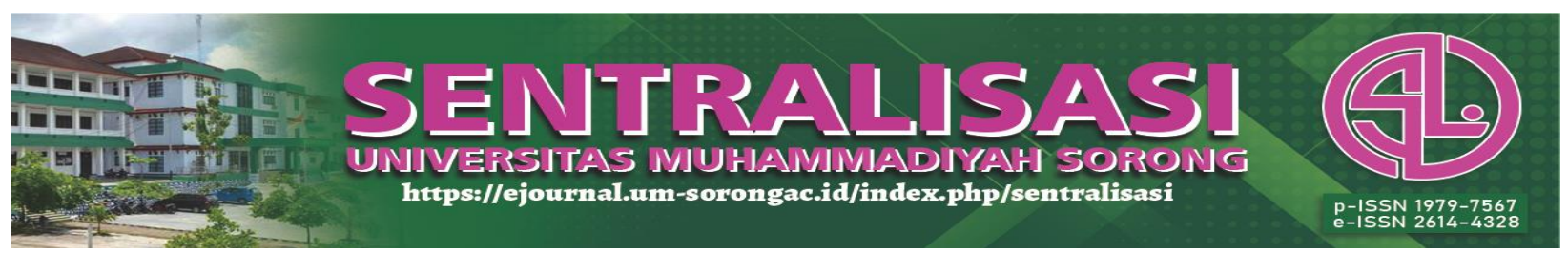

the Lesmana village government, this is because the number of poor people who are entitled to receive BLT Village Fund exceeds the available allocation amount. The mechanism for distributing BLT Dana Desa is usually carried out in two stages, the first stage is carried out formally at the village level according to the recipient data that has been determined in the village meeting, the second stage the funds that have been received are then divided equally at the RT level according to the number of poor people who are entitled to receive BLT Funds Village. This condition makes the amount received, not Rp. 600,000 because it is shared with other residents who are equally in need. The agreement at the RT level is an informal agreement among residents, as a form of empathy and solidarity for the residents of the village of Lesmana because they were both affected by the Covid-19 epidemic .

In managing BLT Dana Desa, the village government of Lesmana has implemented it in accordance with applicable regulations. The accountability of the Village Fund BLT management in Lesmana village is also quite good, this is evidenced by the results of a field survey in which 41 respondents stated that the accountability of the Village Fund BLT management in Lesmana village was quite good. Anomaly occurs at the level of satisfaction with accountability, from 41 respondents only 3 respondents stated that they were satisfied while 38 respondents stated that they were not satisfied. Some of the reasons for community dissatisfaction include very limited information channels about Village Fund BLT, only through village meetings and information from RT heads. Publication of the realization of the BLT Village Fund distribution is only displayed on the village information board, even though there are many other information media that can be maximized by the village government. The lack of channels and information media needs to pay attention to the village government because based on the survey results it is known that all respondents stated that the accountability of BLT Village Fund management is very important. This is a separate note for the Lesmana village government to further improve the accountability of the Village Fund BLT management.

\section{Field Notes From Lesmana}

Field studies conducted by researchers in the form of observations, the distribution of semiopen questionnaires and interviews with community BLT Village Fund recipients found several important notes. These notes were made and presented in accordance with field facts found by researchers when meeting directly with villagers as well as the results of interviews with village officials and representatives of the Lesmana Village BPD. Here is a summary of the record note pitch of the Village Fund BLT findings of researchers at the village Lesmana: 1) Determining the amount of Village Fund BLT, the amount of which is regulated by law, is Rp. 600,000 for stage 1 and Rp. 300,000 for stage 2 and stage 3, making it difficult for the village government because the number of recipients is greater than the amount of aid allocated . This can be seen from the number of proposals for BLT Dana Desa candidates submitted by RT and RW of

Herliana 


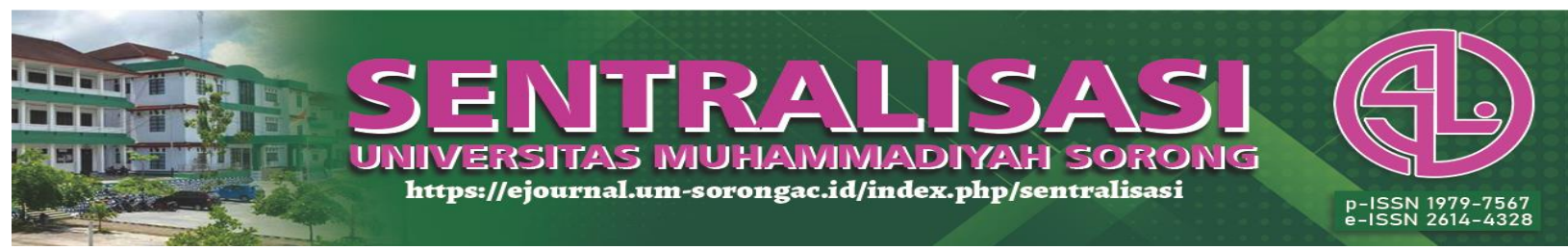

380 poor families, while the allocation of assistance was only for 197 poor families. The villagers of Lesmana then responded to this condition by dividing the amount of assistance for one RT according to the proposed number of poor families. The equal distribution of the Village Fund BLT means that the nominal received by each poor family is less than Rp. 600,000 for the first and less than Rp. 300,000 for the second and third stages. The difference in the amount received by each poor family also made it difficult for the village government to prepare reports on the realization of the Village Fund BLT. Seeing this condition, it seems that the government must review the amount of assistance per poor family. It will be more effective if only the total amount determined by the government, but the amount of each recipient adjusts to the number of potential beneficiaries. So that the village government and the community have the flexibility to distribute according to the number of BLT Village Fund recipient candidates formulated together in village meetings. 2) The implementation of the Village Fund BLT program in the village of Lesmana was somewhat late, the first stage of the village meeting was only held on 17 May 2020, the second stage was 06 July 2020 and the third stage was 27 October 2020. One of the obstacles faced was data verification where the prospective BLT Fund recipients The village has not received other social assistance. At present there are quite a lot of social assistance allocated to the poor, including regular PKH assistance for poor people who have school children, PKH Covid-19 assistance from the Ministry of Social Affairs, and Non-Cash Food Assistance from the provincial government. The problem is that until now there has been no synchronized data (single data) for the recipients of social assistance. With so much social assistance, it takes a long time to verify the data of potential recipients. The reality in the field still occurs that one poor family gets more than one social assistance, while other poor families don't get any social assistance at all. Based on these conditions, the government must unify (single data) using NIK for all social assistance recipients so that all social assistance is really on target. 3) Most of the community felt that information channels related to Village Fund BLT were still very limited, only coming from the local RT / RW Chairman or from the Lesmana village apparatus. Most people expect more channels of information regarding BLT Dana Desa, for example information is conveyed in routine community meetings, published on bulletin boards in the village bale, hamlet bale, RW and RT bale. Information can also be sent via social media groups for the people of Lesmana village. The more channels of information, the more accountability of the Village Fund BLT and reduce the occurrence of errors in the field so that the Village Fund BLT program is truly on target.

Based on information obtained from $m$ a syarakat village Lesmana, one of the programs that is awaited economic recovery program of rural communities. Economic recovery programs that can be carried out include capital assistance for MSMEs, opening jobs for employees affected by layoffs, assistance with tools for the production sector, and digital marketing assistance for local craftsmen. In addition to programs in the form of assistance, the people of Lesmana village also expect the government to support the Lesmana village community in the form of self-management 


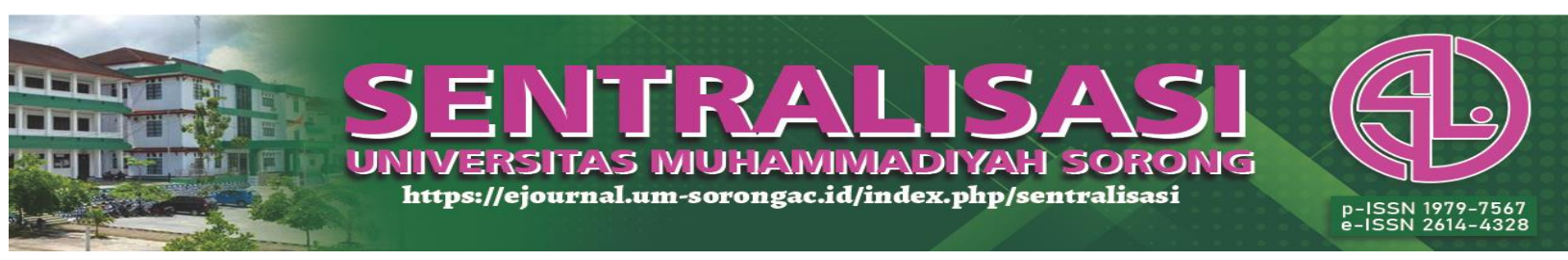

of development activities in the village of Lesmana. Physical development carried out independently by residents of Lesmana village will be one solution to reduce the number of unemployed that has increased due to the impact of the Covid-19 pandemic. Development with a self-managed pattern will also encourage the improvement of the economy of the Lesmana village community. The village community economic recovery program is expected to be the main priority of the Lesmana village government, so that the people of Lesmana village can get up and recover as before the Covid-19 pandemic.

\section{Conclusion}

Pademi Covid-19 has had an impact on reducing the income and income of Lesmana villagers . Many people have experienced a decrease in income and even many people have lost their income because they cannot sell or have been laid off from their jobs. The direct cash assistance program originating from village funds is one of the efforts so that the community can survive during the pademi period.. During 2020, the village of Lesmana has carried out three stages of aid distribution, namely from April to December 2020 with a total distribution of Rp. 199,500,000 . The Village Fund BLT program in Lesmana village has been implemented in accordance with applicable regulations. The first stage of assistance was handed over to 197 families with a nominal value of Rp. 600,000 per family, the second stage for 197 families with a nominal value of Rp. 300,000 per family and the third stage for 74 families out of 80 families who should have received a nominal value of Rp. 300,000 per family. The change in the number of recipients occurred because after re-verification, 6 families had received other social assistance.

The implementation of the Village Fund BLT program has been carried out in an accountable manner, starting from the planning process, data verification, village meetings to determine potential recipients, to the realization of the disbursement of assistance. Based on the results of a survey of the community who received the Village Fund BLT, information was obtained that the accountability of the Village Fund BLT management in the village of Lesmana was quite good. However, there are still many things that need to be improved, such as determining the nominal value of assistance, the need for one data for all social assistance, information channels that must be more diverse and development program priorities after the end of pademi.

This study uses a case study model so that the results of this study can not be generalized to other villages . Factors contingent in the village Lesmana could be different by a factor contingent on the village the other so that most or some of the results of this analysis does not apply in other villages. Future research can expand the research area to a wider scope, for example the scope of districts / cities or the scope of the province and combine with a quantitative approach to produce a more comprehensive analysis.

Herliana 


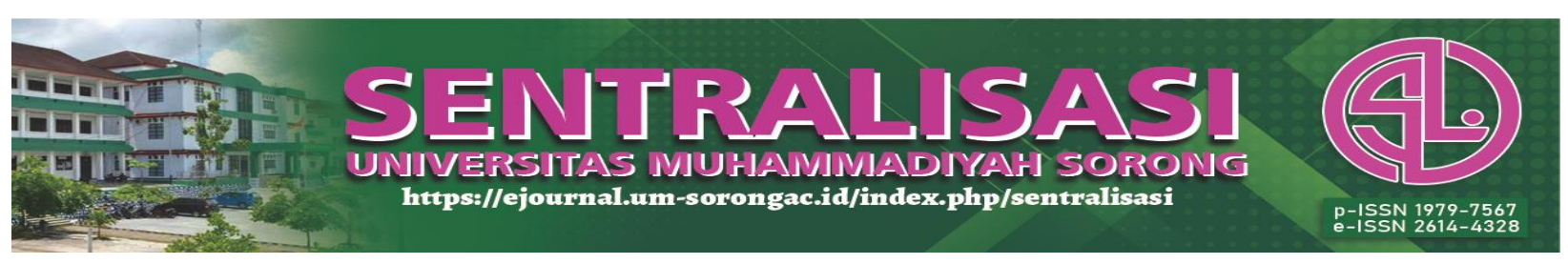

\section{Reference}

Amalia, Z., Malikah, A., \& Mahsuni, A. W. (2020). Transparansi Dan Akuntabilitas Pengelolaan Dana Desa Yang Sesuai Dengan Pelaporan Akuntansi Sektor Publik. E-Jra, 09(02), 47-57.

Asmoro, W. K., \& Setianingsih, N. A. (2019). Akuntabilitas dan Transparansi Pengelolaan Dana "Prodamas" dalam Mewujudkan Good Government Governance di Tingkat Kelurahan Pemerintahan Kota Kediri. Owner, 3(2), 270. https://doi.org/10.33395/owner.v3i2.171

Ayu, A. A., Siahainenia, R. R., \& Kudubun, E. E. (2020). Prioritas Penggunaan Dana Desa Jekawal Kabupaten Sragen Di Era Pandemi Covid-19. Jurnal Analisa Sosiologi, 9(2), 551-566. https://doi.org/10.20961/jas.v9i2.43738

Hanifah, S. I., \& Sugeng, P. (2015). Akuntabilitas dan Transparansi Pertanggungjawaban Anggaran Pendapatan Belanja Desa (APBDes). Jurnal Ilmu \& Riset Akuntansi, 4(8), 1-15.

Hidayat, E. (2020). Implementasi Kebijakan Dana Desa untuk Penanggulangan Pandemi Covid19 di Sampang. Soetomo Communication and Humanities, 1, 126-136.

Maun, C. E. F. (2020). Efektivitas Bantuan Langsung Tunai Dana Desa Bagi Masyarakat Miskin Terkena Dampak Covid-19 Di Desa Talaitad Kecamatan Suluun Tareran Kabupaten Minahasa Selatan. Jurnal Politico, 9(2), 1-16.

Menteri Desa, Pembangunan Daerah Tertinggal, dam T. R. I. (2020). Peraturan Menteri Desa, Pembangunan Daerah Tertinggal, Dan Transmigrasi Republik Indonesia Nomor 11 Tahun 2019 Tentang Prioritas Penggunaan Dana Desa Tahun 2020. Menteri Desa, Pembangunan Daerah Tertinggal, Dam Transmigrasi Republik Indonesia, 53(9), 1689-1699. https://doi.org/10.1017/CBO9781107415324.004

Miles, M. B., \& Huberman, A. M. (1994). Qualitative Data Analysis. In SAGE Publications: Vol. Second Edi.

Nurfaisal, M. D., Murtiarin, D., \& Sakir. (2019). Akuntabilitas Pengelolaan Dana Desa Dalam Pembangunan Infrastruktur Di Desa Tegalrejo Kecamatan Gedangsari Kabupaten $\begin{array}{lllll}\text { Gunungkidul } \quad \text { Tahun } & \text { 2016. }\end{array}$ https://doi.org/10.24198/cosmogov.v5i1.18432

Pramanik, N. D. (2020). Dampak bantuan paket sembako dan bantuan langsung tunai terhadap kelangsungan hidup masyarakat padalarang pada masa pandemi covid 19. Jurnal Ekonomi, Sosial Dan Humaniora, 01(12), 113-120. https://www.jurnalintelektiva.com/index.php/jurnal/article/view/209/149

Rahmansyah, W., Qadri, R. A., Sakti, R. R. A., \& Ikhsan, S. (2020). Pemetaan Permasalahan Penyaluran Bantuan Sosial untuk Penanganan Covid-19 Di Indonesia. Jurnal Pajak Dan Keuangan Negara, II(No.1), 90-102.

Saleh, M., Trishuta Pathiassana, M., \& Faturrahman, F. (2020). Perubahan Alokasi Anggaran Dana Desa Terhadap Pencegahan Covid-19 Di Kecamatan Moyo Hulu. Jurnal TAMBORA, 4(2A), 33-40. https://doi.org/10.36761/jt.v4i2a.767

Saputra, K. A. K., Pradnyanitasari, P. D., Priliandani, N. M. I., \& Putra, I. G. B. N. P. (2019). Praktek Akuntabilitas Dan Kompetensi Sumber Daya Manusia Untuk Pencegahan Fraud Dalam Pengelolaan Dana Desa. Krisna: Kumpulan Riset Akuntansi, 10(2), 168-176. 


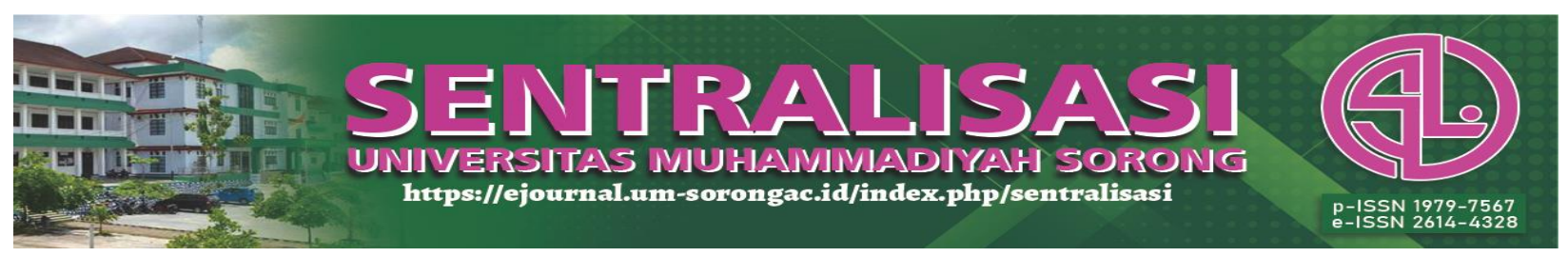

Susliyanti, E. D., \& Binawati, E. (2020). Pengaruh Akuntabilitas Keuangan Dan Akuntabilitas Kinerja Terhadap Kepercayaan Dan Kepuasan Masyarakat Atas Penggunaan Dana Desa. Efektif Jurnal Ekonomi Dan Bisnis, 11(1), 1. 